\title{
ВИХОВНИЙ ПОТЕНЦІАЛ ФІТНЕСУ
}

\begin{abstract}
Рибалко Л. С.
доктор педагогічних наук, професор, професор кафедри освітології та інноваційної педагогіки, керівник науково-методичної лабораторії духовноінтелектуального виховання та навчання, Харківський національний педагогічний університет імені Г.С. Сковороди, м. Харків, Україна
\end{abstract}

\section{Антонов М. С.}

здобувач першого (бакалаврського) рівня вищої освіти ф-ту фізичного виховання і спорту, Харківський національний педагогічний університет імені Г. С. Сковороди, м. Харків, Україна

У статті розкрито виховні функиії фітнесу. Заначено, щзо заняття з фітнесу сприяють розумовому, моральному, естетичному й трудовому вихованню молоді. Тривалі заняття фітнесом зміцннюють духовність людини, розвивають ї̈ інтелект і впевненість у собі.

Ключові слова: фітнес, тренування, вправи, естетичне виховання, фізичне загартування, пандемія.

The article reveals the educational functions of fitness. It is noted that fitness classes contribute to the mental, moral, aesthetic and labor education of young people. Prolonged fitness classes strengthen a person's spirituality, develop his intelligence and self-confidence.

Key words: fitness, training, exercises, aesthetic education, physical training, pandemic.

Фізичне виховання є складовою духовно-інтелектуального розвитку особистості. Завдяки цілеспрямованому зміцненню здоров’я, фізичному загартуванню організму, формуванню життєво важливих рухових навичок розвивається духовність як найголовніша риса інтелектуальної людини, вершина їі розвитку й становлення. Умови подолання пандемії не залишають вибору для людини: потрібно займатися власноруч здоров'ям, загартуванням, зміцненням духу й сили волі. Одним з ефективних шляхів подолання наслідків захворювання коронавірусом є заняття з фітнесу (пілатес, фітнес-йога, каланетика, стрейтчинг, нетрадиційні системи єдиноборств), до яких можуть залучатися люди різного віку.

Дотичними є наукові праці вчених Л. Зеленської, Р. Зеленського (використання потенціалу фітнес-технологій у процесі організації 
Розділ І. Ціннісні орієнтири духовно-інтелектуального виховання, розвиток духовно-інтелектуальних якостей особистості в умовах співпраці й інклюзії

фізичного виховання у закладі вищої освіти), В. Циганія (застосування засобів фітнесу для підвищення рухової активності студентів), Т. Тищенко (методичні поради з використання оздоровчого фітнесу на уроках фізичного виховання).

Мета статті - розкрити виховний потенціал занять із фітнесу.

Цілком погоджуємося 3 автором методичних рекомендацій Г. Тищенко [3] у тому, що фітнес тісно пов'язаний з розумовим, моральним, естетичним, трудовим видами виховної діяльності людини. Заняття фітнесом позитивно впливають на мислення людини, котра аналізує власний стан здоров’я, потреби займатися фізичною культурою, порівнює зміни, що відбуваються унаслідок правильно організованих занять. Головне те, що фітнес надає право вибору людиною здорового способу життя. Як відомо, не кожна людина замислюється над способами дотримання здорового способу життя. Саме усвідомлення необхідності реалізації потреб самореалізації і самозбереження відбувається завдяки заняттям фітнесом.

Звичним явищем є недобросовісне ставлення людини до свого здоров’я, настрою, позитивних емоцій. Нерідко можна почути, особливо в умовах карантину, як усе погано й причиною цього є зовнішні обставини. Звинувачують медичну систему в країні, роботодавців, родичів, сусідів та аби кого. Однак, як на наш погляд, потрібно починати з себе, знаходити шляхи самовдосконалювання й самовиховання. Одним $з$ таких прикладів є заняття фітнесом, завдяки яким змінюється ставлення людини до себе. На нашу думку, заняття загалом фізичною культурою мають стати моральною нормою кожної людини, котра турбується про власне здоров'я, не лягає тягарем на свою сім'ю вразі захворювання.

Під впливом фітнесу формується естетичний смак людини, оскільки такі заняття включають елементи класичної, сучасної хореографії, аеробіки, гімнастики, правильне виконання відповідних вправ. Красиві рухи людини, ïi постава, настрій спонукають до розуміння прекрасного й подолання уживаних стереотипів. Як приклад, кардіотренування з танцювальними рухами допомагають людям різного віку скинути зайві кілограми, підтримувати мя'зи в тонусі, бути красивими й привабливими для себе й оточуючих людей. Та й у професійному середовищі така людина почувається краще й упевнено, вона викликає до себе приємне ставлення з боку колег. 
Фітнес є важкою працею. Заняття фітнесом потребують сили волі, фізичного напруження, витривалості. Досягнення результатів є можливим за умови напруженої розумової й фізичної діяльності впродовж тривалого часу. Під час тривалого фітнес-тренування зростає м’язова сила, зникає втома. Доцільно замітити про те, що вправи під музику позитивно впливають на емоційний стан людини. Негативні думки спливають, а натомість з'являється радість пізнання себе, своїх можливостей, планів і міркувань. Важливим є те, що зростає працездатність і витривалість людини, що так необхідні для виконання поставлених завдань у професійній діяльності.

Отже, фітнес як активний, здоровий, красивий, привабливий стиль життя людини розкрито з позиції його виховних функцій. Доведено, що заняття з фітнесу сприяють розумовому, моральному, естетичному й трудовому вихованню молоді. Тривалі заняття фітнесом зміцнюють духовність людини, розвивають ії інтелект і впевненість у собі.

\section{Список використаних джерел:}

1. Циганій В. В. Застосування засобів фітнесу для підвищення рухової активності студентів. Кваліфікаційна робота на здобуття освітнього ступеня магістра. СДПУ імені А. С. Макаренка. Режим доступу : http:// repository.sspu.sumy.ua/bitstream/123456789/10006/3/\%D0\%A6\%D0\%B8 $\% \mathrm{D} 0 \% \mathrm{~B} 3 \% \mathrm{D} 0 \% \mathrm{~B} 0 \% \mathrm{D} 0 \% \mathrm{BD} \% \mathrm{D} 1 \% 96 \% \mathrm{D} 0 \% \mathrm{~B} 9 \% 20 \% \mathrm{D} 0 \% \mathrm{~A} 0 \% \mathrm{D} 0 \% \mathrm{BE}$ \%D0\%B1\%D0\%BE\%D1\%82\%D0\%B0.pdf (Дата звернення 04.09.2021).

2. Зеленська Л., Зеленський Р. Використання потенціалу фітнес-технологій у процесі організації фізичного виховання у ЗВО. Педагогічні науки. 2019. № 73. С. 72 - 77. Режим доступу : http://dspace.pnpu.edu.ua/ bitstream/123456789/12853/1/ZELENSKA.pdf (Дата звернення: 21.09.21).

3. Тищенко Г. В. Методичні рекомендації з використання оздоровчого фітнесу на уроках фізичного виховання. 2019. 46 с. Режим доступу: https:/ vseosvita.ua/library/tisenko-g-v-metodicni-rekomendacii-z-vikoristannaozdorovcogo-fitnesu-na-urokah-fizicnogo-vihovanna-230992.html (Дата звернення: 15.09.2021). 